\title{
THE WOMAN THAT TURNED INTO A BALL OF FIRE AND WHIPPED ACROSS THE SKY AT NIGHT: RECREATING HISTORY AND MEMORY IN THE DIASPORA
}

\author{
María Alonso Alonso* \\ University of Vigo
}

\begin{abstract}
This paper is focused on interpreting the way in which writers belonging to the Caribbean Diaspora use folklore to investigate concepts like 'time', 'space' and 'bistory' in their ancestors' culture which nowadays appears foreign to a them due to the transterritorialisation that they suffer. David Chariandy's Soucouyant (2007) - among others- will be carefully analysed as an example of novel that uses a folkloric female figure to revise and rewrite the history of colonial and postcolonial women that were persecuted and discriminated against in their countries of origin due to gender and class prejudices. The result of this study suggests that, as Chariandy (2006) indicates, this community has developed tactics to transform even the most traumatic diasporic experiences into instruments of research on, in Umberto Eco's words, "a past that if it cannot be destroyed, at least it is necessary to revisit it without naivety." (Villanueva and Viña-Liste 1991: 36).
\end{abstract}

Keywords: Diaspora, folklore, transculturation and neo-culturation, cultural fictions and stories of cultural haunting.

\footnotetext{
Correspondence should be sent to: María Alonso Alonso. Universidade de Vigo. Email: mariaalonsoalonso@gmail.com
} 


\title{
LA MUJER QUE SE CONVERTÍA EN BOLA DE FUEGO Y RECORRÍA A TODA VELOCIDAD EL CIELO POR LA NOCHE: RECREAR LA HISTORIA Y LOS RECUERDOS EN LA DIÁSPORA
}

\begin{abstract}
RESUMEN. Este trabajo se centra en ofrecer una interpretación de la forma en la que escritores/as pertenecientes a la diáspora caribeña utilizan el folclore para investigar conceptos como 'tiempo', 'espacio' e 'bistoria' en la cultura de sus antepasados ya que ésta se manifiesta como foránea dada la transterritorialización que sufren. Soucouyant (2007) -entre otras-, de David Chariandy, será cuidadosamente analizada como ejemplo de novela en la que se utiliza una figura folclórica femenina para revisar y reescribir la historia de mujeres en contextos coloniales y poscoloniales que fueron perseguidas y discriminadas en sus paises de origen por causa de prejuicios de género y clase. El resultado de este estudio sugiere que, como Chariandy (2006) indica, esta comunidad ha desarrollado tácticas para transformar incluso las experiencias diaspóricas más traumáticas en instrumentos de búsqueda de, en palabras de Umberto Eco, "un pasado que si no puede ser destruido, al menos es necesario revisarlo sin ingenuidad." (Villanueva y Viña-Liste 1991: 36).
\end{abstract}

Palabras clave: Diáspora, folclore, transculturación y neo-culturación, ficciones culturales e historias de obsesiones culturales.

As Derek Walcott once said: "amnesia is the true history of the New World" (Burnet 2000: 81). In postcolonial terms, this means that narratives are interspersed with and rely heavily upon the use of historical flashbacks, which sometimes imply the remembrance of a painful episode that has been repressed or has been manipulated and needs to be reinterpreted. Thus, personal evocation acquires a symbolic dimension where time evolves from a past that survives in illo tempore through folklore. Alternatively, the time represented by historical evocation is connected with official records; however, it is important to take into consideration the perspective from which a text is narrated. In the mythic awareness of postcolonial and diasporic communities, time does flow consistently due to what Ortíz (2002) called Western semi a-culturation of indigenous communities, also known as transculturation. Accordingly, this term refers to the different stages of the process of passing from one culture to another, but this does not imply a severe a-culturation in the strict sense of the word. It rather makes reference to the creation of new cultural implications that Ortíz names as neo-culturation (134). As will be seen, history is usually a fluid mental continuum that changes from one historical period to the next, which might assist a community to create its own distinct spaces depending on the lights and shadows that they want to highlight for 
their own benefit. Therefore, historiography is revealed through literature as a tool for discovering what has been hidden by previous generations. Moreover, folklore constitutes an element to preserve the intangible identity of a community. In a postcolonial context, magic and folklore represent transgression, irreverence and defiance to the colonial influence and the imposed literary models. Consequently, the use of folklore in literature might be regarded as an attempt to recover the stolen cultural legacy, to claim an independent identity and to denounce historical abuse. This is the reason why this article aims to analyse the way in which writers belonging to the Caribbean Diaspora use folklore as a tool to investigate their past. This is done in order to reconcile themselves with a history that in many cases haunts them due to the forced silences imposed by the previous generations who tried to forget or hide certain traumatic experiences that marked their exile.

As a matter of fact, authors of cultural fictions have to deal with constant "changing meanings in which seemingly distinct human cultures encounter one another's 'otherness' - in conditions of profound inequality" (Kolodny 1992: 13). Kolodny talks about inequality in this case because the dialogue existing between these two cultures takes place in the territory of a specific one and, therefore, relegating the other to a secondary place. Despite this, the concurrence of the host-culture and the diasporic-culture is inevitable and, using Shapiro's words, "the encounter between two subjects is not between two 'I's, but two 'we's, and each 'we' is a narrative construction" (1997: 194).

This article will be primarily divided into two main parts. Firstly, the novels of Mootoo and D'Aguiar will be analysed to illustrate the way in which the figure of the soucouyant is connected with the representation of marginal women in certain contexts. Secondly, the work of Chariandy seems to go one step further and articulates the main plot around the myth of the soucouyant to investigate the implications of time and history in second generation immigrant writing through the use of folklore. But before focusing on the texts which will be analysed in this paper, it is necessary to iterate some of the reasons to choose these works. Cereus Blooms at Night (1996) is the first novel written by Caribbean-Canadian Shani Mootoo and tells the story of an old lady who is living in an unknown island which has many reminiscences with the Caribbean due to the vegetation and the weather, although the location of the story is deliberately left ambiguous. In this case, the main protagonist of the novel is considered to be a soucouyant by the whole community, which marks her borderline position in society but, as will be seen, there are a series of factors that mark her consignment to alienation that are directly connected with her labelling as a soucouyant. Another example of borderline character connected with the figure of the soucouyant is one of the characters in English-Guyanese Fred D'Aguiar's Dear Future (1996). In this case, the folkloric element of the novel is directly connected with the figure of a 
witch doctor, which is also something very significant to take into consideration in this study regarding the marginal representation of women under the shape of fantastic characters. But the novel that, without a doubt, will be the focus of this paper is Trinidadian-Canadian David Chariandy's Soucouyant (2007). This novel will serve to analyse and probe that folklore is used in many cases to dig and investigate into historic and familial traumas through literature. Soucouyant is a good example not only to exemplify the way in which Caribbean folklore is reinterpreted in diasporic and postcolonial terms, but also to show the way in which cultural haunting might assist second generation immigrant writers to revise certain historic episodes in their family that have been deliberately silenced in order to make trauma disappear.

Mythographically speaking, a soucouyant is a Caribbean folkloric figure that seems to appear frequently recurrent in diasporic writing. It usually represents marginal women as it is commonly considered to be a female who looks like an old person and lives an apparently ordinary life in the outskirts of a city or village. But at nights, this woman turns into a ball of fire and travels across the sky to suck the blood of her victims while they sleep. It is supposed that the best way to identify a soucouyant is to look for an old neighbour that appears the next morning with bruises all over her body as if she had been beaten up the night before.

In diasporic literature, the figure of the soucouyant normally emerges in relation to women that carry some kind of cultural or familial burden. This misfortune usually reduces them to being alienated characters, rejected by society and pushed into the background. In many cases, we find examples of this social repudiation under the shape of rumours that work in many cases as the carrier of prejudices against marginal women from generation to generation. In most cases, the line that separates rumours from facts is extremely thin and this turns gossip into something actually occurring in a realistic context. This is, for example, the case of Shani Mootoo's Cereus Blooms at Night in which Mala, the female protagonist of the novel, is considered to be a soucouyant by the locals. References to her figure, as will be seen, are used by parents to prevent children from doing certain things. These kinds of elements seem to exist in most cultures in order to make children fear to do things such as going out at night alone or staying up until too late. This is probably the reason why in different cultures we find figures such as the Galician Tártaro, the Spanish Coco or the English Bogeyman. In this particular case, a soucouyant could be considered as the female version of her European male counterparts, which is quite significant in terms of gender characterisation.

In Mootoo's novel, Mala is subjected to a cruel social discrimination during all her life due to the terrible situation she experiences at home. This situation is known and accepted by the villagers who do nothing during Mala's childhood 
to prevent her father committing incest with her. As it usually happens, marginal women who are rejected by society are, in many cases, victims of the indifference of those around them and do absolutely anything to prevent certain situations. In the case of Cereus Blooms at Night, the reader is presented with Mala's traumatic childhood from the outset. The narrator introduces the sexual abuse that the protagonist suffers from her father very early in the novel through constant flashbacks. This has the effect of shifting the context from the present, where Mala is a very old woman living in a geriatric hospital, right back to her childhood. Through these flashbacks the reader discovers her family history and, above all, that she is the victim of her father's terrible sexual assaults from a very early age; something that the whole village knew but did not prevent. The social response to child abuse in this case is marginality. Mala is consigned to oblivion which favours her otherness and her labelling as a soucouyant who, according to rumours that exist in the village, whips across the sky at night to "track an offending child into its hiding place and tear out its mind" (Cereus: 113).

In other cases like in Fred D'Aguiar's Dear Future, the figure of the soucouyant also seems consistent but in this case it is used to refer to a witch doctor. Like in Carpentier's novel El reino de este mundo, published for the first time in 1949, the African-Caribbean magical view of the world is represented here in a folkloric manner through the spiritual superiority of the quack. In El reino de este mundo, it was Maman Loi who bridged the gap between the supernatural and the physical; in Dear Future, Miss Metage is the one who serves this purpose when she is visited after official medicine failed to cure Red Head from a terrible accident that he suffered and which gave him "his name and visionary capacity" (Dear: 3). Rumours, once again, work as a carrier of culture because even though Miss Metage is socially respected as she is the witch doctor of the village, she also has to carry the stigma of being considered a woman who "flew on a broom and turned into a ball of fire in order to get through keyholes to babies' cots" (Dear: 28). She also lives in the edge of the village and, even though she is appreciated due to her spiritual superiority, her condition as a witch doctor makes her marginal. Actually, considering that the previous quotation is uttered by Red Head, who is the child protagonist of the novel, this rumour might also be a sign of the ambivalent process to which Miss Metage is being subjected to the extent that she is identified with a soucouyant.

After this brief introduction around the figure of the soucouyant in the previously mentioned Caribbean diasporic texts, this paper will focus on a specific novel that perfectly illustrates the way in which folklore serves to recreate history and memory in the Diaspora. Soucouyant is the first novel written by CaribbeanCanadian David Chariandy. The story is set in Toronto and narrates the return home of a son who has to look after his mother who suffers from dementia and who 
involuntarily starts revealing the family's disturbing history. The magical element of the novel appears very early in the narration when Adele, the protagonist's mother, assures her son that she met a soucouyant in real life when she was living in Trinidad, her country of origin. It is at this point when the two levels of the narration - the public and the private - intermingle by using constant flashbacks from the time of the narration in Canada to the time of the main story plot in Trinidad. Thus, the official history of Trinidad that is constantly recalled represents the public, whereas the family history that is slowly reconstructed by the son represents the private. Even though these two levels seem independent, there is a close connection between them because public or official history is constructed sometimes by the omission of private or unofficial histories of suffering peoples. Indeed, Chariandy (2008) himself considers that it is necessary to rethink what the past means to discover what has been omitted from the official records. This is even more important in the case of diasporic communities due to the detachment and dislocation from cultural referents experienced by immigrants.

The two levels of narration previously referred also correspond with two of the main concepts of the novel: history and memory. In Soucouyant, the official Trinidadian and the non-official family histories are built through fragmented evocations of personal experiences. If the narrator is able to reconstruct Trinidadian history around the figure of the soucouyant this is because Adele suffers from a neurological illness that affects memory. Dementia in this case is the catalyst to explore the fragility of cultural memory. As a matter of fact, forgetting is in many cases a strategy used to silence personal experiences of abuse and violence. Therefore, Adele's control to keep her painful past silenced vanishes due to the fact that she suffers from dementia and it is then when she starts revealing all the memories that she has been keeping in her subconscious. Actually, forgetting is a common procedure that people used to get on with life without having to remember all the painful, embarrassing or traumatic experiences that they have had during all their life. This is exactly what happens in many diasporic communities. Diaspora is usually linked to extreme living conditions where escaping, emigration or exile becomes the only way of survival and this is why all these stories are silenced in many cases by those who suffered them.

In Soucouyant, Adele represents this diasporic painful experience. Her forgetting-to-forget helps her son to construct the family history from the small details that she reveals. The novel succeeds in showing this process of reconstruction as fragmented and slow where, once more, the mother, a female figure, is the carrier of the family history. This reconstruction takes place through Adele's son, who is the one that gives form to all the sketches that he recollects from what his mother says concerning her encounter with a soucouyant. Moreover, this reconstruction goes from present to past, or what is the same, from Adele's son own experiences 
in Canada, to his mother's experiences between two countries and two cultures of encounter, and ending with his grandmother's in Trinidad.

As this paper stated from the outset, folklore and mythography are research instruments used by some diasporic writers, especially second generation immigrant writers, to investigate into the history of their countries of origin. The figure of the soucouyant in general is an intrinsic part of Caribbean folklore but for the main protagonist in Chariandy's novel, it is a foreign word that haunts him. Accordingly, a soucouyant could be considered as the representation of the protagonist's Caribbean legacy that happens to be unrelated to him because it does not represent him anymore. This is why he needs to interpret the supernatural phenomenon that his mother talks about in rational terms. Apparently, the protagonist of Soucouyant has to confront his own rational code when this is directly challenged through his perception of the supernatural that his mother describes when she talks about her encounter with a soucouyant. In this case, the materialisation of the marvellous dimension of the Caribbean for the protagonist is nothing but the confrontation between his mother's faith-based view of the world and his own interpretation of that code. In a Caribbean context, the existence of soucouyants is not questioned by the locals because it is an intrinsic element of their everyday life. What is more, a soucouyant for a Caribbean person is not even a folkloric superstition but part of their cultural reality. Notwithstanding this, the same experience agitates Western rationalism because it challenges this system of belief, which is exactly what happens to Adele's son when he questions his mother's encounter with a soucouyant. Therefore the soucouyant in the novel is not only a myth belonging to the Caribbean folklore but it stands out as the representation of Caribbean culture and history in a public level, as well as the protagonist's family past experiences in a private level. Both levels under the shape of this mythical figure appear to be completely mysterious and exotic for the protagonist due to the detachment that he suffers from his culture of origin and from his own family.

According to what has been previously said, folklore in this case is the tool that the narrator uses to investigate into the protagonist's history. Since Adele's son is the focaliser of the narration, the reconstruction of the public historical level starts from the protagonist's nearest present to the further past. Canada is used in the novel to exemplify the migratory movements that characterised the last decades of the $20^{\text {th }}$ century. First, the narrator seems to follow the official version offered by the Canadian government:

Canada relies, as it has throughout its history, on immigrant labour not just to expand but to continue to exist. Immigrants are at the heart of its cultural and economic identity. Multiculturalism does not deny that immigration remains the flow of labour to capital, and not the flow of idealists to an idea [...] Multiculturalism in Canada posits a plurality of origin, of heritage, and of contribution, and if its 
disadvantage has been the persistence of an Anglo-Canadian central referent, its advantage has been a level of dignity for migrant labour unmatched by any other immigrant nation. (Soucouyant: 133)

But as the protagonist starts digging into his family past, he discovers how Canada, as an example of multicultural country, has not been as idyllic as official reports want to show. This is the point in which Adele's arrival in the country to work as a domestic manifests as the first traumatic point of friction in her silenced history. Racism in Canada is obviously not a new phenomenon and white-only signs were actually common even during the last century. Soon after she arrived in the country, Adele encountered one of her most disturbing moments when she entered a white-only shop to buy a meringue pie which she always aspired to purchase when she passed by a restaurant and saw displayed "many desserts and often a lusciously tall lemon meringue pie" (Soucouyant: 49). Adele had always been fascinated by the word 'meringue' after reading it in magazines and hearing it in movies and on the radio. Unfortunately for her, she had never been able to taste that "fluffy sweetness as exotic [for her] as snow" (Soucouyant: 49). The exotic was what the meringue pie represented for Adele: the exoticness of being in Canada, a foreign country. But one day, she was able to gather the courage that entering a restaurant with a white-only sign on the entrance required and decided to buy one of those pies. Consequently, as soon as the bells on the door of the restaurant announced her entrance, Adele, as a black woman in Canada, was immediately racialised and labelled as the other due to her skin colour:

'Look what just walked in', a voice says.

Nobody comes to seat her. She's not sure what to do, and so she moves toward an empty table. She sits down and still nobody comes. Finally, a man with salt-andpepper hair and a nice white shirt slides into the seat. He asks if she wants to fuck. He asks again, and she hears but doesn't hear, and she looks around again [...] The man leaves and another man approaches. He's the owner and he softly explains that this is a family restaurant and that no coloured or prostitutes are allowed to eat here. (Soucouyant: 49)

"Coloured" and "prostitutes" are given the same status and clearly segregated from what the owner considers appropriate for a family restaurant. But, continuing with the narrator's dismantling of the Canadian official discourse of the nation as being an example of inclusive policy in which several different cultures coexist in harmony, the novel even dares to question the very existence of Canada as a nation. Accordingly, one of the most interesting points in the novel is the destruction of the foundational myth. Many countries embellish their history to give it a mythological aura that will symbolise splendidly their constitutional make up as a nation. But it should also be borne in mind that history implies a high 
degree of subjectivity due to its constant selection and manipulation. To keep this mythological aspect of history, the cruellest accounts are usually silenced. Soucouyant contests the Canadian official foundational myth by exposing the injustices over which the nation was created. This is possible thanks to the figure of Miss Cameron who explains to the protagonist that Canada was founded mainly after stealing the land from the First Nations:

I learned about the 'Toronto Purchase' of land from three Mississauga chiefs in 1787, but also how no document describing a neighbouring 'Scarborough Purchase' has ever come to light. I mostly learned about our community of Port Junction, which was established early in the 1800s when several United Empire Loyalists migrated up from the US to set up the first farming settlements to the east of the fledgling town. (Soucouyant: 103)

Once the protagonist fragmentally reconstructs the history of Canada, his homeland, by questioning the official version that the government offers in its records, the narrator goes further by focusing on Adele in order to follow this same process with Trinidadian history, which in this case will be recalled through the protagonist's family history. It is in this part that the two levels of narration clearly intermingle into a single one where the private, in this case, serves to represent the public. Therefore, Adele's family history stands out to illustrate Trinidadian official history. Once again, in this fragmented part of the narration, the storyline is centred on the figure of the soucouyant who represents in the novel the very essence of Trinidadian cultural legacy since, as it has already been mentioned, it symbolises the protagonist's haunting past.

In the public domain, Trinidadian history is presented through the colonisation, exploitation and abuse of the island and its inhabitants. Miss Cameron is once again the catalyst for the protagonist's curiosity about the country where his mother and grandmother were born. He learns from official documents that Trinidad was an extremely important colony for the British Empire from an economic point of view due to the richness of its territory that included the production of sugar, coffee and, above all, oil which represented "three-quarters of the oil for the entire British Empire" (Soucouyant: 106) around 1917. But Trinidad was also amazingly seductive for many nations due to its importance as a strategic military point in the Caribbean. This is probably the main reason why during the Second World War the Americans took advantage of European instability and established their military base in the island.

Regarding the official version of history, the novel directly questions the validity of this discourse by presenting two versions of the same story that recreate the construction of the North American military base in Trinidad. The fact that there are two sides of the same coin, one official and the other silenced, implies 
a high degree of manipulation in which obscure episodes in history are not only hidden but also negated:

These historians and activists also would point out that a significant number of the blacks and South Asians who were expelled from Chaguaramas during the constructions of the base were never properly compensated. Many state workers were forced to abandon their livelihoods and homes for desperately needed pittances, and a great many, in fact, received no more compensation than one-way transportation to 'approved' sites such as the struggling fishing village of Carenage. [...] But other historians would offer what they described as a more 'balanced' perspective on these events. After all, the world was at war, and proper measures needed to be taken, even if this meant inconveniencing a few illiterates who, most likely, would not have grasped the severity of the situation, had it been explained to them. And in any event, the American presence appeared to offer genuine benefits to at least some of the local inhabitants. Those eking out a meagre living on struggling plantations had the chance to earn Yankee dollars as road workers, maids, and latrine differs. (Soucouyant: 178-179)

Violence and abuse mark the presence of foreign control in the island all the way from its recent past to its early history. The two islands of Trinidad and Tobago, as many other islands in the Caribbean, were colonised firstly by the Spaniards who decimated the Arawak population that inhabited the land. Once the Spanish lost interest in these islands, other foreign nations took control and installed a plantation system through which thousands of African slaves arrived to work in the fields. After the abolition of the slave trade and the massive migration of the black population, Chinese, Portuguese and East Indians entered the islands as workforce. Finally, the gradual independence of Trinidad and Tobago was achieved starting in the 1930s after the establishment of the US military bases in Chaguaramas and Cumuto, an episode extremely important in Soucouyant, and ending with the declaration of independence from the United Kingdom in 1962. But it was in the 1980s when the main mass migration movements to Canada and the US followed the Black Power riots that emerged from a high social and political instability caused by the oil bust and the North American military interventionism.

As Varela (1996: 253-268) points out in her work on the aesthetic implications of magical realism, the reconstruction of the past through history implies a strong need of returning and all the accounts that the narrator brings back to the present acquire a mythical magnitude. Varela talks about mythical magnitude in relation to the function of folklore which, according to her, is transformed through memories moving its perception from sensorial to mythical. In order to do this, it is necessary to merge the past into the present and, thus, the concept of time vanishes and the past is then transformed into a mythical present through memory. Hence, this return ad originem represents a new dimension for the 
existence of Adele's son in which the recreation of historical accounts transforms the present.

The evocation of the furthest past is constructed in Soucouyant through evocations of family history. Therefore, this part of the essay is going to leave aside the public level mentioned in previous paragraphs where Trinidadian official history is revisited by the protagonist in order to focus on the private level of the narration that will serve to fill in historical gaps and to give voice to the silenced particular stories of Trinidadians. It is in this section where Adele's dementia plays a fundamental role due to the fact that her forgetting-to-forget is the catalyst for the fragmented recount of her traumatic experiences. From the first stages of her mental deterioration, before it becomes severe, Adele starts giving some hints about her encounter with a soucouyant. These experiences help the narrator to construct the protagonist's family history back in Trinidad, where this encounter took place.

Regarding the relation that exists between cultural fictions and national identity, there seems to be an agreement among critics in highlighting the strong connection that exists between mythography and folklore, as well as between these and patriotism or national identity (Gennep 1982, Kirk 1985, Coupe 1997, Neeson 1998). This is why myths and folklore are in many cases considered as the sediment of the imagery of a community that developed from ancient received truths and beliefs. Generally speaking, the main role of myths and legends in a community is to give answers to natural, social and biological phenomena. Actually social imagination plays a really important role in the creation and transmission of folkloric elements. This idea was already developed by Ricoeur who considered that "imagination may function to preserve an order [although it] may have a disruptive function" (Coupe 1997: 96). He considered that the function of imagination to preserve an order in society is represented by the ideology of a group, which is directly connected with national identity. Indeed, some of the most determinant factors that favoured the constitution and transmission of myths and legends is chauvinism at national, local or even familial levels. This is probably the reason for the increasing interest in studying folkloric elements in different communities during the $19^{\text {th }}$ century. Gennep (1982: 8) puts the onus on the political content of folklore and on the contribution of myths and legends on the building of national identities. Folklore nowadays is one of the main tools that a community has in order to reinterpret their mythic cultural and national past by means of their historical present which, paradoxically and as Bhabha highlights, "destroys the constant principles of the national culture that attempts to hark back to a 'true' national past" (1990: 303). This reinterpretation might imply a high degree of selection and manipulation done in order to accommodate a national past that sometimes might not correspond with the image that is aimed to offer 
in the present. When the construction of a specific national culture is achieved after ignoring or consciously hiding the violence that was required to found that community as a nation, the evocation of those selected episodes by a group of people (second generation immigrant writers in this case) challenges the official historical version of certain dominant cultures.

Past and present are, therefore, constantly related in the legendary imagery of a community. Mnemotecnia serves as the instrument to formulate legends that will recover the past through collective and individual memory. Myths and legends link the general with the particular because, obviously, these are two connected concepts. Particular experiences are the result of general circumstances, and general experiences are made up from small particular accounts. Magical realism and marvellous realism are, in this case, the vehicles of connection between past and present in literature to bring together the folkloric inheritance of a community.

In relation to the magical dimension of the soucouyant in the novel, it should be emphasised that the first time Adele mentions this folkloric figure is through indirect references such as the following: "Chaguaramas', she explained. 'She loss she skin at the military base in Chaguaramas. She wore a dress of fire before it go ruin her'" (Soucouyant: 24). Adele's early memories from when she was just a child come back to the present from her subconscious. She recalls the vision of this female figure that, as is suggested, had an accident in which her dress burnt causing severe injuries in her body. But this is just the beginning. For Adele, as for her son, the soucouyant represents their haunting past. Thanks to the oral transmission that is going to take place in the text, her family history does not fall into oblivion; actually, if Adele did not reveal these memories, these experiences that haunt the family members would vanish with her death and would never be recovered.

From the middle of the novel onwards, the narration clearly focuses on interpreting Caribbean folklore in the Diaspora by using a marvellous realistic literary technique. Adele's son hardly pays attention to what his mother says about her encounter with a soucouyant. It is from the moment in which the protagonist starts feeling interested in Trinidadian history that he starts listening to what his mother says and tries to put two and two together.

Soucouyant as an example of a return ad originem novel succeeds in presenting and questioning the image of Canada and Trinidad as multicultural nations. This representation, as already explained, is made from mixing the public and private levels of historical accounts in the novel. It is interesting to note the fact that the public level that is illustrated through official history symbolises the written legacy of a community (that in most cases must be questioned due to the high degree of manipulation that history implies); contrarily to this, the private level is represented in many cases by the intangible oral heritage that most communities have and 
which is here constructed through folklore. This novel, as many other diasporic writing, involves a mixture between textual and social analysis which illustrates the importance of immigrant peoples in establishing what Bhabha (1990) called the nation-space. This idea of identity draws attention to some of the hidden and silenced traumatic consequences of postcolonial past and forced migration in the delimitation of a physical and imaginary representation of that nation-space. For Hall (1995), second and third generation immigrants have an extremely important role in the process of identity building because for him identity is not in the past to be found, but in the future to be constructed. What Hall implies with this statement is that people should not interpret identity as draconian but as a process that is in continuous formation. Therefore, the past should indeed be revisited but without disregarding the importance of the present moment and the future in the interpretation of a community's identity.

Finally, in relation with the historical connection that has existed between Trinidad and Canada, Harley (1996) offers an excellent study on the importance of culture in the construction of identity in the Diaspora. First of all, he questions the assimilation of the Caribbean as a single region commenting that, even though there are obvious historical and cultural links, the national interests that differentiate the Spanish, French and English speaking regions are quite significant. Regarding Trinidad, it seems that Soucouyant succeeds on representing this multicultural dimension of both topographical references in the text. Accordingly, as Harley notes, Trinidad has always been a cosmopolitan island with a rich artistic outpouring. Still, ethnicity in Trinidad and also in most parts of the Caribbean, as Fischer states, is a concept which is continuously being rediscovered and reinvented as it is a "process of assuming an ethnic identity [through] a pluralistic, multidimensional, or multifaceted concept of self: one can be many different things, and this personal sense can be a crucible for a wider social ethos of pluralism" (Harley 1996: 121). But, unfortunately, this is not always as ideal as Fischer theorises. In Soucouyant there is a clear example of race and class lack of solidarity where not even race and national identity serve to maintain this positive attitude towards fellowship. This example of cultural incoherence is embodied in Mrs. Christopher who is an occasional character in the novel but who represents this sense of lack of social affinity. The first time she appears in the text is as an ambivalent character; at a first moment, she seems to care for Adele's welfare, but at the same time, Adele reacts suspiciously towards her: "Now that woman ... that older woman there. She frighten me quite a bit"' (Soucouyant: 87). Soon after, the narrator includes in the text some bits of this character's past. She went to Canada for the same reasons as Adele's, to work as a domestic. Mrs. Christopher and Adele were friends before they received their landed status, that is to say, before they were legal immigrants. They planned a trip to the mountain to see the snow, which 
is a fascinating phenomenon for a Caribbean person, but something happened during that excursion; something that the protagonist's mother never revealed but something painful enough to forget or hide from the others. After Adele's death, Mrs. Christopher does not show any empathy towards the situation which Adele's son finds himself, despite the difficulties that both women suffered due to their immigrant status in Canada. It is even to the point that Mrs. Christopher asks Adele's son for economic compensation for having looked after her friend when Adele was living alone.

Summing up, Chariandy's intention with his first novel, according to his own words, was to illustrate the cultural problematic that second generation immigrant writers have to deal with. A strong sense of disaffection and unsuitability saturate this kind of literature with a constant presence of ghosts and haunting creatures that come from another world to threaten them. He considers that this haunting is directly linked to second generation immigrant writers' ethnic legacy that enters into confrontation with their Western scepticism. Forgetting offers to first generation immigrants a relief because history is often a cruel nightmare. Therefore, forgetting represents an urgent need to come into terms with daily life. Actually, Chariandy insisted on the danger of forgetting the dramatic consequences of colonialism in so many places. Adele has in Soucouyant a painful story of her own past that wants to hide to her siblings and for this reason she tries to forget that traumatic past but the irony is that her dementia constitutes her process of forgetting-to-forget and, thus, she starts revealing all those repressed and suppressed memories. Chariandy also commented on the fact that, despite the reflection of second generation immigrants' ethics, their parents' past haunts them due to the everlasting silences and gaps left in history. First generation immigrants in many cases want to tell romanticised stories about their homeland but the next generations do not want to hear that. It is when the story of the past has not been told adequately that ghosts appear. The author also considers that when someone is forgetting stories of the past, someone else has to remember them; otherwise these accounts would eventually disappear. This is exactly what happens in Soucouyant, where the protagonist represents the importance of oral tradition or storytelling for the preservation of history. This is why second and third generation immigrants have to revisit and reinterpret what their parents keep hidden in their subconscious. Their role in their society is incredibly important from an anthropological point of view and that is why cultural fictions, as in this case, serve to preserve past and history by their reinterpretation in the Diaspora.

In Soucouyant, as well as in Cereus Blooms at Night and in Dear Future, the marvellous realistic atmosphere created through the figure of the soucouyant is the instrument that the narrators use to explore and transgress boundaries, as Zamora and Faris point out, "whether the boundaries are ontological, political, 
geographical or generic" (1995: 5). Folklore here represents what Brogan (1998) refers to as "stories of cultural haunting", where the myth is "an enigmatic transitional figure moving between past and present, death and life, one culture and another (6). In Chariandy's and Mootoo's works, the soucouyant is a cultural figure that haunts the protagonists in order to survive, otherwise the family horror would fall in oblivion with the death of the matriarch who is the last person in the family saga who knows the true story of their past.

\section{ACKNOWLEGMENTS}

With the support of the European Social Fund and the General Secretariat of Universities of the Department of Education of the Galician Autonomic Government (Xunta de Galicia).

\section{REFERENCES}

Bhabha, H. K. 1990. "Dissemination: Time, Narrative and the Margins of Modern Nation". Nation and Narration. Ed. H.K. Bhabha. London: Routledge. 291-322. Brogan, K. 1998. Cultural Haunting: Ghosts and Ethnicity in Recent American Literature. Charlottesville: University Press of Virginia.

Burnet, P. 2000. Derek Walcott: Politics and Poetics. Florida: Florida University Press.

Carpentier, A. 2003 (1949). El reino de este mundo. Madrid: Alianza Editorial.

Chariandy, D. 2007. Soucouyant. Vancouver: Arsenal Pulp Press.

Chariandy, D. 2006. "Postcolonial Diasporas".

http://postcolonial.org/index.php/pct/article/view/440/839 (Accessed 18 July 2009).

Chariandy, D. 2008. "Diasporic Literatures in Canada".

http://tv.uvigo.es/gl/serial/398.html (Accessed 10 October 2008).

Coupe, L. 1997. Myth. London: Routledge.

D'Aguiar, F. 1996. Dear Future. London: Chatto \& Windus.

Gennep, A. 1982. La formación de las leyendas. Barcelona: Alta Fulla. Trans. Ramona Violant Ribera.

Hall, S. 1995. "Negotiating Caribbean Identities". New Left Review, January-February: 3-14.

Harley, S. 1996. Nationalism and Identity. Culture and the Imagination in a Caribbean Diaspora. Kingston: University of the West Indies. 
Kirk, G. S. 1985. El mito. Su significado y funciones en la Antigüedad y otras culturas. Barcelona: Paidós. Trans. Teófilo de Loyola.

Kolodny, A. 1992. "Letting Go Out Grand Obsessions: Notes Toward a New Literary History of the American frontiers". A Companion to the Regional Literatures of America. Ed. C. L. Crow. Oxford: Blackwell Publishing. 42-56.

Mootoo, S. 1996. Cereus Blooms at Night. London: Granta Books.

Neeson, E. 1998. Mitos e lendas celtas. A Coruña: Toxosoutos. Trans. Ana Suárez Piñeiro.

Ortíz, F. 2002 (1940). Contrapunto cubano del tabaco y el azúcar. Madrid: Cátedra.

Shapiro, M. J. 1997. Violent Cartographies: Mapping Cultures of War. Minneapolis: University of Minnesota Press.

Varela Bran, M. del C. 1996. Funcionalidad de las claves estéticas del realismo mágico en la novela hispanoamericana. Pontevedra: Excma. Diputación de Pontevedra.

Villanueva, D. and J. M. Viña Liste. 1991. Trayectoria de la novela hispanoamericana actual, del 'realismo mágico' a los años ochenta. Madrid: Espasa Calpe.

Zamora, L. P. and W. B. Faris. 1995. Magical Realism: Theory, History, Community. Durham: Duke University Press. 